\title{
Pelagic production and the recruitment of juvenile polar cod Boreogadus saida in Canadian Arctic seas
}

\author{
Mathieu LeBlanc ${ }^{1} \cdot$ Maxime Geoffroy $^{2} \cdot$ Caroline Bouchard $^{3} \cdot$ Stéphane Gauthier $^{4} \cdot$ Andrew Majewski $^{5}$. \\ James D. Reist ${ }^{5} \cdot$ Louis Fortier $^{1}$
}

Received: 20 December 2018 / Revised: 21 August 2019 / Accepted: 23 August 2019 / Published online: 5 September 2019

(c) The Author(s) 2019

\begin{abstract}
Previous work found that an earlier ice breakup favors the recruitment of juvenile polar cod (Boreogadus saida) by enabling early hatchers to survive and reach a large size by late summer thanks to a long growth season. We tested the hypothesis that, in addition to a long growth season, an earlier ice breakup provides superior feeding conditions for young polar cod by enhancing microalgal and zooplankton production over the summer months. Ice cover and surface chlorophyll $a$ were derived from satellite observations, and zooplankton and juvenile cod biomass were estimated by hydroacoustics in ten regions of the Canadian Arctic over a period of 11 years. Earlier breakups resulted in earlier phytoplankton blooms. Zooplankton backscatter in August increased with earlier breakup and bloom, and plateaued at chlorophyll $a>1 \mathrm{mg} \mathrm{m}^{-3}$. Juvenile cod biomass in August increased with an earlier breakup, and plateaued at a zooplankton backscatter $>5 \mathrm{~m}^{2} \mathrm{nmi}^{-2}$, supporting the hypothesis that higher food availability promotes the growth and survival of age- 0 fish in years of early ice melt. However, there was little evidence that late summer biomass of either zooplankton or age-0 polar cod benefitted from ice breakup occurring prior to June. On average, zooplankton standing stock was similar in the Southern Beaufort Sea and the North Water-Lancaster Sound polynya complex, but juvenile cod biomass was higher in the Beaufort Sea. Intense avian predation could explain the lower biomass of juvenile cod in the polynya complex, confirming its reputation as a biological hotspot for energy transfer to higher trophic levels.
\end{abstract}

Keywords Boreogadus saida $\cdot$ Juvenile recruitment $\cdot$ Zooplankton · Ice breakup date $\cdot$ Phytoplankton bloom · Canadian Arctic Ocean

This article belongs to the special issue on the "Arctic Gadids in a Changing Climate", coordinated by Franz Mueter, Haakon Hop, Benjamin Laurel, Caroline Bouchard, and Brenda Norcross.

Electronic supplementary material The online version of this article (https://doi.org/10.1007/s00300-019-02565-6) contains supplementary material, which is available to authorized users.

Mathieu LeBlanc

mathieu.leblanc.10@ulaval.ca

1 Québec-Océan, Department of Biology, Université Laval, Québec, QC G1V 0A6, Canada

2 Centre for Fisheries Ecosystems Research, Marine Institute of Memorial University of Newfoundland, St. John's, NL A1C 5R3, Canada

\section{Introduction}

The polar cod (Boreogadus saida), a small forage fish, dominates the pelagic fish assemblage in Arctic seas (Fortier et al. 2015). It plays a pivotal role in the transfer of energy from zooplankton to Arctic predators, thus changes in its abundance in response to climate change could alter the services provided to northern communities by the pelagic ecosystem (Welch et al. 1992; Tynan and DeMaster 1997; Darnis et al. 2012). The larvae hatch from January to early July and develop

3 Greenland Climate Research Centre, Greenland Institute of Natural Resources, Kivioq 2, 3900 Nuuk, Greenland

4 Institute of Ocean Sciences, Fisheries and Oceans Canada, Sidney, BC V8L 4B2, Canada

5 Freshwater Institute, Fisheries and Oceans Canada, Winnipeg, MB R3T 2N6, Canada 
in the epipelagic layer $(0-100 \mathrm{~m})$ over spring and summer (Bouchard and Fortier 2008, 2011; Geoffroy et al. 2016). By September and October, age- 0 juvenile polar cod initiate an ontogenetic downward migration and recruit progressively to the adult stock in the mesopelagic layer as their size increases (Geoffroy et al. 2016). The abundance and biomass of epipelagic age- 0 polar cod in August and September, before this migration, is believed to be a predictor of recruitment to the adult population (e.g., polar cod in Bouchard et al. 2017; other gadids in Laurel et al. 2016).

In the Canadian Arctic, the biomass of juvenile polar cod in August and September increases exponentially with earlier ice breakup $(<50 \%$ ice cover $)$ and warmer spring-summer sea surface temperatures (Bouchard et al. 2017). Only the late hatchers survive in years of late ice breakup, resulting in fewer and smaller fish in the fall. In years of early ice breakup, early hatchers survive and enjoy a long growth season, which results in more abundant and heavier fish in the fall. Differences in recruitment to the juvenile stage can be large: juvenile polar cod biomass in September can be 11 times greater for an early May ice breakup compared to a late September ice breakup (Bouchard et al. 2017). Juvenile recruitment was strongly correlated to ice breakup date and sea surface temperatures (SST), two correlated abiotic drivers. However, Bouchard et al. (2017) suspected that the survival of early hatchers in years of early ice breakup is enhanced by biotic factors such as an advanced bloom of ice algae and phytoplankton (e.g., Kahru et al. 2011) and the resulting earlier and more intense production of copepod nauplii and copepodites (Fortier et al. 1995; Ringuette et al. 2002; Daase et al. 2013), the preferred prey of age-0 polar cod (Michaud et al. 1996; Bouchard et al. 2016).

In this study, new data are added (18 region-year combinations in August and 12 in September) to further explore the correlation between ice breakup date and the biomass of juvenile polar cod in late summer reported by Bouchard et al. (2017). We also test the prediction that increased juvenile recruitment in years of early ice breakup is correlated to an earlier phytoplankton bloom and the resulting higher availability of zooplankton. Phytoplankton bloom onset date and acoustically estimated zooplankton standing stock in the fall are used as indices of the production of the pelagic ecosystem over the summer months. Pelagic production and the recruitment of juvenile polar cod are contrasted among three provinces of the Canadian Arctic: Southern Beaufort Sea in the Arctic Ocean Basin proper, the shallow Kitikmeot region in the central Archipelago, and Northwest Baffin Bay including the North Water-Lancaster Sound polynya complex.

\section{Materials and methods}

\section{Study area}

The Canadian sector of the Arctic Ocean extends from the Beaufort Sea in the West to Baffin Bay in the East (Fig. 1). The sector is divided into several regions by the Canadian Ice Service based on sea-ice characteristics and regime (www.ec.gc.ca/glaces-ice). Typically, these regions are covered by ice for most of the year, with ice breakup occurring from May to September or not at all depending on the year (Bouchard et al. 2017; National Snow and Ice Data Center 2018). From 2006 to 2017, 63 hydroacoustic-trawl surveys of variable duration (1 to 30 days) were completed in ten of these regions in August and September (Fig. 1, Table 1) as part of the ArcticNet annual expedition of the research icebreaker CCGS Amundsen to the Canadian Arctic Ocean (2006-2017) and the Fisheries and Oceans Canada surveys aboard the trawler F/V Frosti in the Beaufort Sea (2012-2014). Overall, valid hydroacoustic estimates of zooplankton and juvenile polar cod biomass were obtained for 40 region-year combinations in August and 23 in September(Table 1).

The ten regions surveyed span three main oceanographic provinces (Fig. 1). Southern Beaufort Sea in the west comprises the productive Mackenzie Shelf with intermittent upwelling at its northeast edge (Carmack and Kulikov 1998; Carmack et al. 2004); the mouth of the Amundsen Gulf with the large Cape Bathurst polynya (Stirling 1980; Arrigo and van Dijken 2004; Williams and Carmack 2008); and the deep Amundsen Gulf. The Kitikmeot region in the Southern Canadian Arctic Archipelago (CAA) is characterized by shallow $(<220 \mathrm{~m})$ gulfs, sounds and straits (Coronation-Queen Maud gulfs, Larsen Sound-Victoria Strait), and deeper $(<420 \mathrm{~m})$ sounds and channels (Peel Sound, M'Clintock Channel). Northwest Baffin Bay includes the productive North Water and Lancaster Sound polynya complex, and the western Baffin Bay region (Fig. 1). The west-east general circulation carries surface waters from the Beaufort Sea to Baffin Bay through the shallow CAA (Wang et al. 2012). Biologically, polar cod and the large copepods Calanus hyperboreus and Calanus glacialis dominate pelagic biomass in the deep Beaufort Sea and NW Baffin Bay, while benthic fish and smaller copepods characterize the shallow Kitikmeot (Bouchard et al. 2018, Darnis et al. unpublished data). The North Water and Lancaster Sound polynya complex is considered one of the most biologically productive regions of the Arctic Ocean (e.g., Stirling 1980; Barber et al. 2001; Tremblay et al. 2002). 


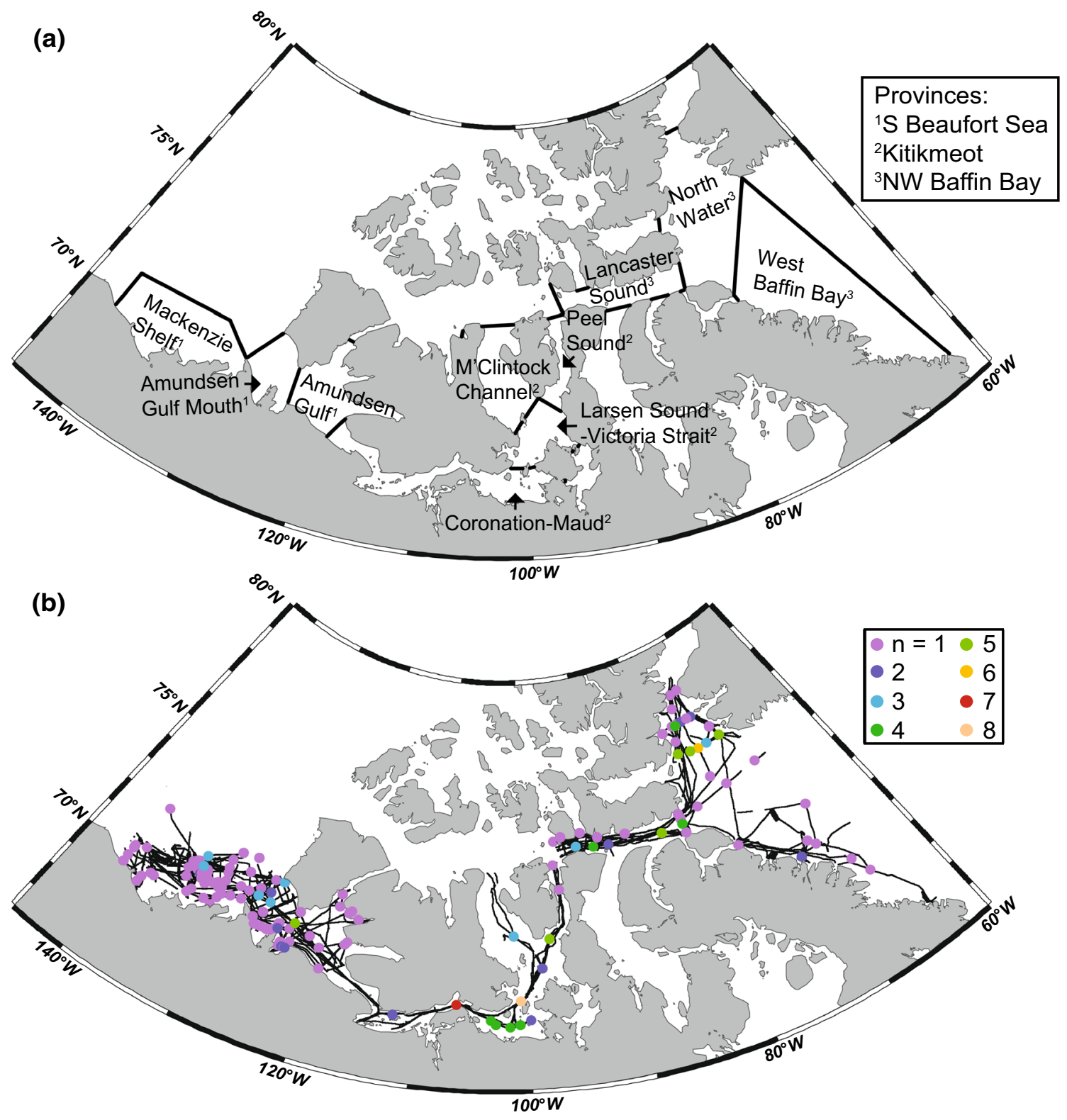

Fig. 1 a Limits of the ten Canadian Ice Service regions analysed in the study grouped by the Southern Beaufort Sea, Kitikmeot and Northwest Baffin Bay oceanographic provinces. b Hydroacoustic and ichthyoplankton surveys from 2006 to 2017. Black lines represent

\section{Remote sensing of ice and $\mathrm{Chl} a$}

Ice breakup week (IBW) in a given region-year was defined as the week during which ice concentration fell below $50 \%$ (Scott and Marshall 2010) using the Canadian Ice Service data (www.ec.gc.ca/glaces-ice).

For each region-year, the mean chlorophyll $a$ concentration from 1 April to 31 August ( $\mathrm{Chl} a$ ) was estimated using Level 3 daily Aqua MODIS remote-sensing data at a $4 \mathrm{~km}^{2}$ resolution (https://oceancolor.gsfc.nasa.gov/cgi/l3). hydroacoustic transects. Colored dots are the locations of ichthyoplankton sampling stations with color indicating the number of net samples at each location over the study period

Daily sea-ice concentration was assigned to each Chl $a$ concentration from the nearest most overlapping pixel of the 25-km resolution Defense Meteorological Satellite Program (DMSP) Special Sensor Microwave Imager (SSM/I)-Special Sensor Microwave Imager/Sounder (SSMIS) (https://nsidc .org, 2006-2016) and of the 12.5-km resolution IFREMERCERSAT (ftp.ifremer.fr/ifremer/cersat 2017) datasets. Pixels of Chl $a$ concentration with ice concentration $>15 \%$ were removed from the analysis to avoid possible contamination of the ocean color signal. For a given region-year, the 
Table 1 Date range of ichthyoplankton and hydroacoustic sampling periods in each region: Southern Beaufort Sea: $M S$ Mackenzie Shelf, $A G M$ Amundsen Gulf Mouth, $A G$ Amundsen Gulf; Kitikmeot: $C M$ CoronationMaud, $L V$ Larsen SoundVictoria Strait, $M C$ M'Clintock Channel, PS Peel Sound; and Northwest Baffin Bay: $L S$ Lancaster Sound, $N W$ North Water, $W B B$ West Baffin Bay

\begin{tabular}{|c|c|c|c|c|c|c|c|c|c|c|c|}
\hline Month & Year & MS & AGM & AG & $\mathrm{CM}$ & LV & $\mathrm{MC}$ & PS & LS & NW & WBB \\
\hline \multirow[t]{8}{*}{ August } & 2010 & $14-28$ & & & & $9-10$ & & $8-9$ & $6-8$ & & \\
\hline & 2011 & & & & 9-12 & $8-9$ & & $7-8$ & $2-7$ & & \\
\hline & 2012 & $6-31$ & & & & & & & & & \\
\hline & 2013 & $24-31$ & $1-24$ & $10-20$ & & & & & $13-31$ & $14-29$ & $9-12$ \\
\hline & 2014 & $2-31$ & $17-21$ & & $11-16$ & & & $10-11$ & & $1-7$ & \\
\hline & 2015 & $25-30$ & $22-30$ & 22 & $17-21$ & 17 & & $16-17$ & $9-14$ & & $5-9$ \\
\hline & 2016 & $29-31$ & $27-29$ & $26-27$ & $20-26$ & $19-20$ & & 19 & $4-18$ & $4-17$ & $1-3$ \\
\hline & 2017 & & & & $8-10$ & $7-10$ & & & $2-5$ & & \\
\hline \multirow[t]{8}{*}{ September } & 2006 & & & & $24-27$ & & $23-24$ & & $6-23$ & $6-20$ & \\
\hline & 2007 & & & & & & & & & $28-30$ & \\
\hline & 2008 & & & & & & & & $2-9$ & $9-23$ & $10-30$ \\
\hline & 2011 & $2-30$ & $1-30$ & & & & & & & & \\
\hline & 2013 & & & & & & & & $3-29$ & & \\
\hline & 2014 & $1-24$ & & $24-25$ & & & & & & & \\
\hline & 2015 & & & & $19-22$ & $22-23$ & & & $25-30$ & & \\
\hline & 2016 & $1-6$ & & $15-16$ & $16-20$ & 20 & $21-22$ & & $23-25$ & & $26-29$ \\
\hline
\end{tabular}

No sampling in 2009

phytoplankton bloom start date (BSD) was defined as the day when the daily mean Chl $a$ concentration exceeded $20 \%$ of the maximum daily mean Chl $a$ concentration from 1 April to 31 August (Platt et al. 2009; Marchese et al. 2017).

\section{Hydroacoustic estimates of polar cod and zooplankton}

Ichthyoplankton nets and trawls were deployed (Fig. 1b, Table 1) from the surface to depths varying from 10 to $100 \mathrm{~m}$ to ascertain the epipelagic fish assemblage and validate the acoustic signals (details in Bouchard et al. 2017). The fresh standard length (SL) of individual age-0 polar cod was measured on the ship and their weight (W) was calculated based on $W=0.0055$ (SL) ${ }^{3.19}$ (Geoffroy et al. 2016). Data from the two ships for a given region-year were pooled.

Hydroacoustic data were recorded continuously along the track of the ships (Fig. 1b, Table 1) with a Simrad EK60® split-beam echosounder at 38 and $120 \mathrm{kHz}$ (nominal beam angle of $7^{\circ}$ ). The ping rate varied from $\sim 1$ to $2 \mathrm{~s}$ depending on maximum depth, and pulse duration was set to $1024 \mu \mathrm{s}$. Power was $2 \mathrm{~kW}$ at $38 \mathrm{kHz}$ and $500 \mathrm{~W}$ (2006-2011) or $250 \mathrm{~W}(2012-2017)$ at $120 \mathrm{kHz}$. The co-located transducers were calibrated annually using the standard sphere method (Demer et al. 2015). Conductivity-Temperature-Depth (CTD) profiles from the Amundsen (SBE-911 plus $®$ ) and the Frosti (SBE-25® and SBE-19 plusV2®) were used to determine sound speed in water (Mackenzie 1981) and the coefficient of sound absorption (Francois and Garrison 1982) for the acoustic analysis. The echograms were all scrutinized to correct bottom detection by the sounder and to discard noise and signals from other deployed instruments. A time-varied threshold (TVT $=20 \log R+2 \alpha R-140$, where $R$ is the range from the transducer) was also added in the 38 and $120 \mathrm{kHz}$ echograms to offset noise amplification at depth by the time-varied gain (e.g., Geoffroy et al. 2016). A minimum $(-90 \mathrm{~dB})$ and a maximum $(-40 \mathrm{~dB})$ volume backscattering strength $\left(\mathrm{S}_{\mathrm{v}} ; \mathrm{dB}\right.$ re: $\left.1 \mathrm{~m}^{-1}\right)$ threshold was applied on the data at both frequencies (Benoit et al. 2014; Geoffroy et al. 2016).

The difference in mean volume backscattering strength $\triangle$ MVBS (dB re: $1 \mathrm{~m}^{-1}$ ) between 38 and $120 \mathrm{kHz}$ was used to discriminate polar cod from zooplankton $\left(\triangle \mathrm{MVBS}_{120-38}\right.$ in the range $-10 \mathrm{~dB}$ to $5 \mathrm{~dB}$, Benoit et al. 2014; Geoffroy et al. 2016). Monthly mean size (SL and W) of polar cod sampled by nets and the nautical area backscattering coefficient (NASC, $\mathrm{m}^{2} \mathrm{nmi}^{-2}$ ) in echo-integration cells ( 0.25 nautical mile long by $3 \mathrm{~m}$ deep) at $38 \mathrm{kHz}$ were used to estimate age- 0 polar cod integrated biomass $(\mathrm{mg}$ $\mathrm{m}^{-2}$ ) from $13.5 \mathrm{~m}$ (effective sampling depth of the transducers) to $100 \mathrm{~m}$. Monthly (August and September) mean integrated age- 0 polar cod biomass (B) was calculated for each region-year surveyed (Table 1).

By excluding fish in the top $13.5 \mathrm{~m}$ of the water column and at the ice-water interface, our acoustical estimates of age- 0 polar cod biomass are underestimating total biomass. The proportion of the age- 0 population excluded from the estimates is poorly documented, but the bias is assumed constant across years and regions.

A proxy for zooplankton density in the epipelagic layer $(13.5-100 \mathrm{~m})$ was calculated using NASC $\left(\mathrm{m}^{2} \mathrm{nmi}^{-2}\right)$ in echo-integration cells at $120 \mathrm{kHz}$. To discriminate zooplankton backscatter from that of fish and macrozooplankton, only cells with $\Delta \mathrm{MVBS}_{120-38}>12 \mathrm{~dB}$ (Madureira et al. 1993) were kept in the echo-integration. 
Monthly mean zooplankton backscatter (Zoo) was calculated for each region-year.

Copepods dominate the zooplankton of Canadian Arctic seas with the large Calanus hyperboreus and C. glacialis herbivores making up 50 to $90 \%$ of the zooplankton biomass and small species such as Pseudocalanus spp., Oithona similis, and Triconia borealis prevailing by numbers (Darnis et al. 2008, 2012). We thus assumed that the acoustic signal attributed to zooplankton is dominated by these species.

All hydroacoustic data analyses were performed with Echoview® 7.1.

\section{Statistics}

Spearman's rank correlations were first tested between abiotic and biotic variables and among biotic variables as exploratory analyses. Each relationship was further investigated using simple linear mixed-effects regression models. In models that included Chl $a$ or zooplankton backscatter as independent variables, these variables were ln-transformed based on a visual examination of scatterplots, as well as on the theory of predator-prey interactions (Holling 1959). Region of sampling was included in the models as a random effect. Relationships between zooplankton backscatter or age- 0 polar cod biomass and ice breakup week or phytoplankton bloom start date were also evaluated using secondorder mixed-effects models. Linear and second-order mixedeffects models were compared with the Akaike information criteria (AIC). Marginal $r^{2}$ was calculated for each model (Nakagawa and Schielzeth 2013). Dependent variables in the relationships were $\ln$-transformed prior to statistical analyses to achieve approximate homoscedasticity and normality of model residuals.

Average onset date of the phytoplankton bloom, zooplankton backscatter in August, and age- 0 polar cod biomass in August were compared among oceanographic provinces with a one-way ANOVA and a Tukey HSD test.

Statistical analyses were conducted with R® version 3.2.3 (R Core Team 2015).

\section{Results}

\section{Ice breakup, microalgal bloom, zooplankton and juvenile polar cod biomass}

Across the region-years, the onset date of the phytoplankton bloom was significantly influenced (slope $=0.020$, $p=0.002$ ) by the ice breakup week (linear mixed-effects model, Fig. 2a; Online resource 1a). Chl $a$ averaged over the period 1 April to 31 August was significantly correlated to ice breakup week (Spearman's rank correlation, $p<0.001$ ), although the effect was not statistically significant in the linear mixed-effects model (slope $=-0.018, p=0.108$ ). Earlier ice breakup tended to result in greater surface microalgal biomass over spring-summer (Fig. 2b; Online resource 1b).

Based on the linear mixed-effects model, zooplankton backscatter in the epipelagic layer $(13.5-100 \mathrm{~m})$ in August increased with an earlier ice breakup week (slope $=-0.170, p<0.001)$ and an earlier phytoplankton bloom (slope $=-0.015, p=0.014)$ (Fig. 3a, b; Online resource 2a). An early ice breakup in May increased zooplankton backscatter up to 116-fold relative to a late ice breakup in September (Fig. 3a). A second-order mixedeffects model $\left[\ln (\mathrm{Zoo})=1.11-4.92 \mathrm{IBW}-2.89 \mathrm{IBW}^{2}\right]$ yielded a higher coefficient of determination (marginal $r^{2}=0.51 \mathrm{vs}$. $0.36)$ and a lower AIC value (110.8 vs. 118.7) than did the linear mixed-effects model (Fig. 3a), suggesting that zooplankton backscatter was maximum for an ice breakup in early June. Based on a second-order mixed-effects model as well (marginal $r^{2}=0.23$ vs. 0.17 ; AIC value $=122.5$ vs. 124.4), zooplankton backscatter peaked when the surface bloom started in late May (Fig. 3b). Despite much noise in the relationship, zooplankton backscatter in late summer tended to increase initially with spring-summer Chl $a$ (slope $=0.453, p=0.363$ ), and then to plateau at $\mathrm{Chl}$ $a>1 \mathrm{mg} \mathrm{m}^{-3}$ (Fig. 3c).

Biomass of age- 0 polar cod $\left(\mathrm{mg} \mathrm{m}^{-2}\right)$ in August in the epipelagic layer increased with an earlier ice breakup (slope $=-0.254, p<0.001)$ (Fig. 4a; Online resource 3a). Polar cod biomass in August was $~ 16$ times higher for the earliest ice breakup on week 19 (early May) compared to the latest ice breakup on week 36 (early September). As for zooplankton backscatter, the residuals of the linear mixedeffects regression tended to be positive in June and negative before and after, suggesting that juvenile polar cod biomass in August was maximum when the ice broke up in June. A second-order mixed-effects model also yielded a slightly higher coefficient of determination (marginal $r^{2}=0.47$ vs. 0.44) and a lower AIC value (135.6 vs. 142.6) than did the linear mixed-effects model (Fig. 4a). Age-0 polar cod biomass in August increased with zooplankton backscatter (slope $=0.762, p<0.001$ ) until it reached a plateau at zooplankton backscatter $>5 \mathrm{~m}^{2} \mathrm{nmi}^{-2}$ (Fig. $4 \mathrm{~b}$ ).

The relationships found in August between abiotic and biotic variables and among biotic variables were also detected in September but at lower statistical significance levels (Online Resources 2 to 5).

\section{Bloom onset date, zooplankton standing stock and juvenile polar cod biomass across oceanographic provinces}

The onset date of the phytoplankton bloom averaged over years tended to be more variable in regions of the Southern Beaufort Sea than in the regions of the other two 
Fig. 2 a Bloom start day (BSD) and $\mathbf{b}$ average surface chlorophyll $a$ concentration from 1 April to 31 August (Chl $a$ ) in relation to ice breakup week (IBW) for all region-years (filled symbols: August; open symbols: September; $n=52$ ) over the period of study. Solid lines are the linear mixed-effects regression models and dashed lines are the $95 \%$ confidence intervals. Regression equations are given with the $p$ value of the slope and marginal $r^{2} . \rho$ is the Spearman's rank correlation
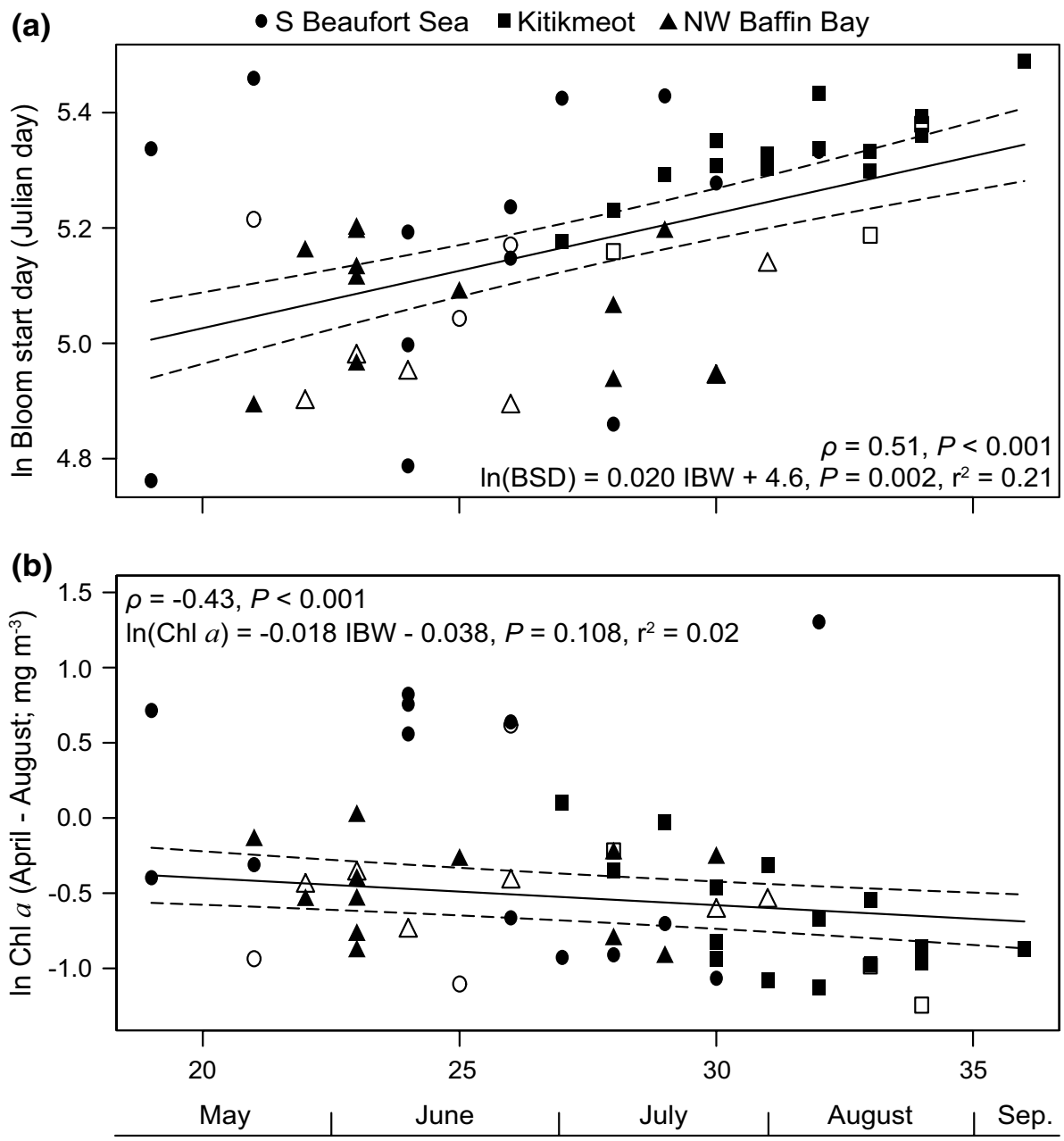

Ice breakup week

-S Beaufort Sea - Kitikmeot $\Delta$ NW Baffin Bay

(a)

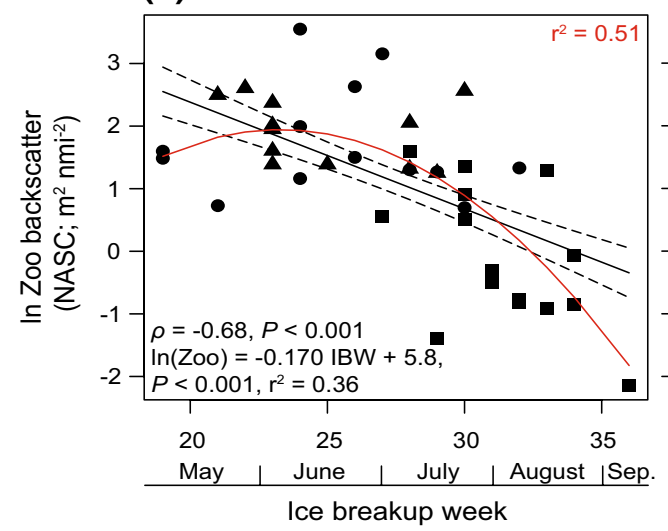

(b)

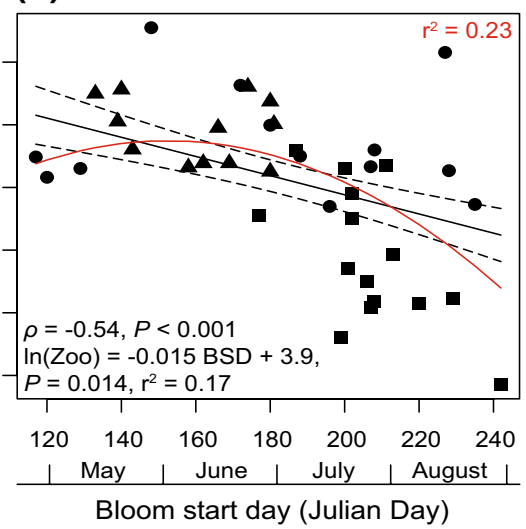

(c)

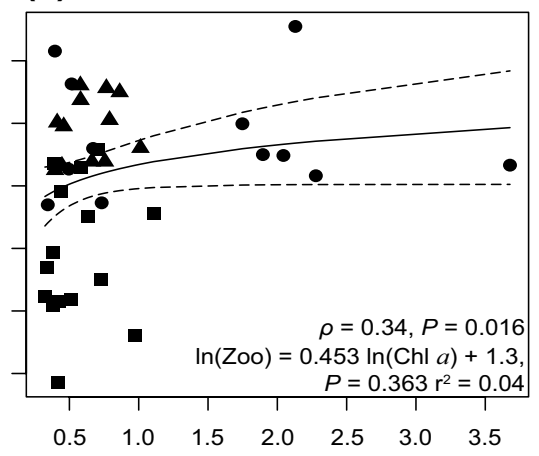

Chl $a$ (April - August; $\mathrm{mg} \mathrm{m}^{-3}$ )
Fig. 3 Mean epipelagic zooplankton backscatter (Zoo) in August $(n=40)$ in relation to a ice breakup week (IBW), b bloom start day (BSD), and $\mathbf{c}$ mean surface chlorophyll $a$ concentration from 1 April to 31 August $(\mathrm{Chl} a)$. Solid black lines are the $(\mathbf{a}, \mathbf{b})$ linear or $\mathbf{c}$ logarithmic mixed-effects regression models and dashed lines are the $95 \%$ confidence intervals. Regression equations are given with the $p$ value of the slope and marginal $r^{2} . \rho$ is the Spearman's rank correlation. Red curves (a, b) are second-order mixed-effects regression models fitted to the data (see Results) 
(a)

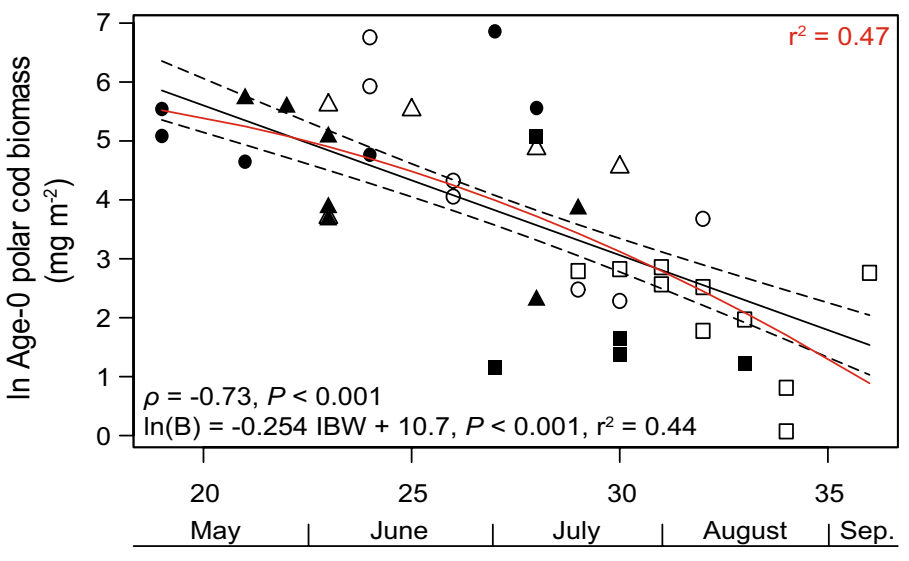

Ice breakup week (b)

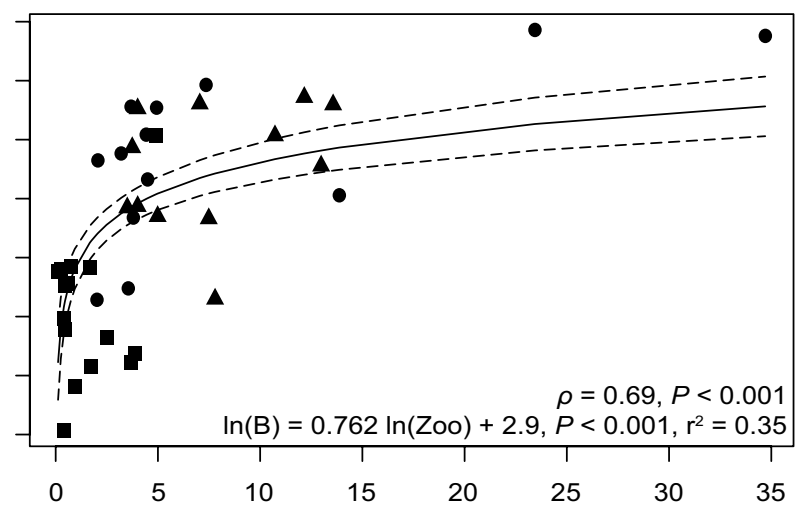

Zoo backscatter (NASC; $\mathrm{m}^{2} \mathrm{nmi}^{-2}$ )
Fig. 4 Mean epipelagic age-0 polar cod biomass (B) in August $(n=40)$ in relation to $\mathbf{a}$ ice breakup week (IBW), and b mean epipelagic zooplankton backscatter (Zoo) in August. Solid lines are the a linear or $\mathbf{b}$ logarithmic mixed-effects regression models and dashed lines are the $95 \%$ confidence intervals. Regression equations are

oceanographic provinces (Fig. 5a). Bloom start dates were significantly later (Tukey HSD test, $p<0.05$ ) in the Kitikmeot province of the Canadian Archipelago, and showed no statistical difference between the Southern Beaufort Sea and NW Baffin Bay.

Mean acoustic estimates of zooplankton density in August were similar in the deep Southern Beaufort Sea and deep NW Baffin Bay and significantly lower (Tukey HSD test, $p<0.05$ ) in the shallow Kitikmeot (Fig. 5b).

Juvenile polar cod biomass in August averaged over region-years was highest in Southern Beaufort Sea $\left(\right.$ mean $\left.=252 \mathrm{mg} \mathrm{m}^{-2}\right)$, intermediate in NW Baffin Bay $\left(\right.$ mean $\left.=139 \mathrm{mg} \mathrm{m}^{-2}\right)$ and lowest in the Kitikmeot (mean $=19 \mathrm{mg} \mathrm{m}^{-2}$ ) (Fig. 5c).

\section{Discussion}

\section{Early ice breakup and summer pelagic production}

In the strongly pulsed primary production cycle of Arctic seas, microalgal biomass first develops in spring at the icewater interface (Horner 1985; Sakshaug and Slagstad 1991; Søreide et al. 2010). Thanks to early removal of the snow cover over the ice or to leads allowing light to penetrate the surface waters, phytoplankton sometimes blooms before the ice breakup (Haecky et al. 1998; Fortier et al. 2002; Arrigo et al. 2012; Assmy et al. 2017). However, the surface phytoplankton bloom typically starts in the weeks following ice breakup and then deepens towards the nitracline to given with the $p$ value of the slope and marginal $r^{2} . \rho$ is the Spearman's rank correlation. Red curve a is a second-order mixed-effects regression model fitted to the data (see Results). Open symbols represent data presented in Bouchard et al. (2017)

form a sub-surface chlorophyll maximum (SCM) (Martin et al. 2010). With an increasingly late freeze-up allowing wind mixing, a second surface phytoplankton bloom is now observed in autumn in many Arctic seas (Ardyna et al. 2014).

By allowing light penetration, an earlier ice breakup triggers an earlier phytoplankton bloom (e.g., Ringuette et al. 2002; Kahru et al. 2011; Leu et al. 2011), which results in a longer season of production and, despite the possibility of nutrients becoming limiting in some regions (Tremblay et al. 2012), an overall greater primary production over the spring-summer (Arrigo et al. 2008; Arrigo and van Dijken 2015). Satellite observations detect neither ice microalgae, under-ice phytoplankton, nor deep SCMs (Arrigo and van Dijken 2015). Hence, the remote-sensing measurements of surface Chl $a$ used here certainly underestimated the overall microalgal biomass available to zooplankton grazers over spring-summer (e.g., Assmy et al. 2017). Nevertheless, surface Chl $a$ averaged from April to August, our crude index of ecosystem primary production, was correlated to ice breakup week (Fig. 2). Bloom start date, which dictates the duration of the period of food availability to zooplankton grazers, also depended on ice breakup week as reported previously (e.g., Ringuette et al. 2002; Søreide et al. 2010; Leu et al. 2011).

First-feeding polar cod larvae prey on copepod eggs and the naupliar stages of small copepods such as Pseudocalanus spp. and Oithona similis, whereas juveniles shift their diet to the nauplii and early copepodite stages of the larger Calanus spp. (Fortier et al. 1995; Michaud et al. 1996; Bouchard et al. 2016). An early ice breakup in the North Water relative to 

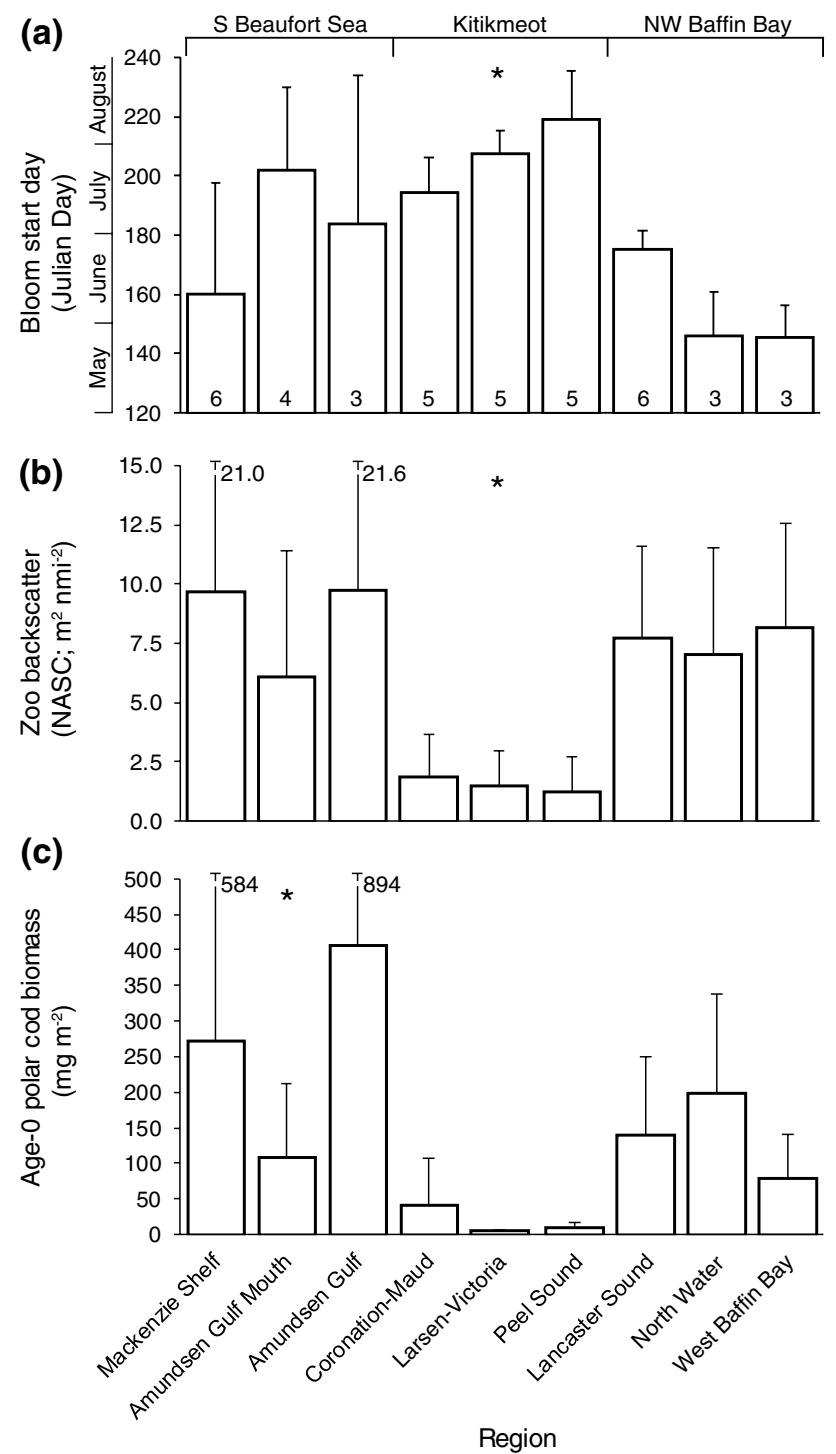

Fig. 5 Mean values over the study period of a bloom start day, $\mathbf{b}$ epipelagic zooplankton backscatter in August, and c epipelagic age- 0 polar cod biomass in August, for different regions of the Canadian Arctic grouped by oceanographic provinces. Number of years analysed over the study period is indicated in bars of panel (a). No values were measured in August in M'Clintock Channel. Oceanographic province with significantly different values based on one-way ANOVA and Tukey HSD test $(p<0.05)$ is represented by an asterisk

Barrow Strait led to the earlier production and higher densities of Pseudocalanus spp. and Calanus spp. early copepodite stages (Ringuette et al. 2002). As well, Leu et al. (2011) observed a temporal mismatch between the algal bloom and the growth of the new copepod generation when ice broke up late in Rijpfjorden (Svalbard) in 2008. These authors suggested that very early ice breakups and algal blooms could also disconnect herbivorous zooplankton from its food, leading to lower population levels, as has been also observed at lower latitudes in the Bering Sea (Hunt et al. 2002).
In the present study, zooplankton backscatter in August was more strongly correlated to ice breakup date and phytoplankton bloom onset date than to $\mathrm{Chl} a$ concentration (Fig. 3), indicating that the duration of the season of food availability rather than food abundance likely was the primary driver of the late summer biomass of zooplankton. Over a 4-month range in ice breakup and phytoplankton bloom dates (early May to early September), zooplankton backscatter in August generally increased with an earlier breakup and bloom (Fig. 3). Yet, a close inspection of the relationship reveals that maximum backscatter in August was achieved for ice breakups and blooms occurring in late May and June and that, consistent with the prediction of Leu et al. (2011), the few instances of very early breakup and bloom in May were correlated with somewhat lower zooplankton backscatter in August (Fig. 3a, b). Statistically, the adjustment of a second-order mixed-effects model depicting this maximum in zooplankton recruitment for late May-June breakups and blooms explained a larger fraction of the variance $\left(r^{2}\right)$ in zooplankton backscatter in August and resulted in a better model (lower AIC) than a linear mixedeffects model (Fig. 3a, b). Maximum zooplankton backscatter would point to June as the threshold over which climate warming and an ever earlier ice breakup would stop benefiting the present zooplankton assemblage in Arctic seas.

\section{Pelagic production and juvenile polar cod recruitment}

Statistical relationships linking fish recruitment to some environmental factor often fail with the addition of new observations, in particular if these come from outside the range of conditions for which the initial relationship was established (Frank 1997; Myers 1998; Leggett and Frank 2008). The addition of 18 new data points for August (from 22 to 40) to the relationship reported by Bouchard et al. (2017) confirmed the link between juvenile polar cod biomass in the fall and the date of ice breakup (Fig. 4a). This suggests that the environmental conditions in Canadian Arctic seas have not yet changed enough to modify the forcing of polar cod recruitment by sea-ice dynamics.

Polar cod is often associated with the ice-water interface and sometimes observed within anfractuosities in the sea ice (Lønne and Gulliksen 1989; Gradinger and Bluhm 2004; Søreide et al. 2006; Melnikov and Chernova 2013; David et al. 2016). This raises the possibility that in region-years of late ice breakup, some age- 0 polar cod would ascend to the ice-water interface in August-September, escaping detection in the $13.5+\mathrm{m}$ layer ensonified by our echosounder. The concentration of juvenile polar cod at the ice-water interface or within the top $13.5 \mathrm{~m}$ of the water column could explain in part the estimated low biomasses of age- 0 fish in years of late breakup. In the central Arctic Ocean, polar cod sampled 
at the ice-water interface with the Surface and Under Ice Trawl (SUIT) in August and September were age- $1+$ fish from 52 to $140 \mathrm{~mm}$ SL (David et al. 2016). The $0.3 \mathrm{~mm}$ mesh of the inside net of the SUIT should have retained age-0 polar cod if any were distributed at the ice-water interface. Other studies also reported that polar cod associated with sea ice were mostly age- 1 and age- 2 fish (Lønne and Gulliksen 1989; Melnikov and Chernova 2013). While further studies of sea ice as habitat for age-0 polar cod are warranted (Geoffroy et al. 2016), these observations do not support the hypothesis of a significant migration of age- 0 polar cod to the ice-water interface in the fall.

The dependence of juvenile polar cod biomass on ice breakup date can be interpreted in two non-exclusive ways (Bouchard et al. 2017). First, polar cod larvae hatch from as early as January to the first weeks of July (Bouchard and Fortier 2008, 2011). Higher recruitment in late summer could solely result from the fact that an early ice breakup provides early hatching larvae with the minimum temperature and feeding conditions to survive and benefit from a long growth season, leading to abundant and large fish in August. Warmer summer temperatures and more abundant food would play no significant role in polar cod survival and recruitment. Second, in addition to minimum conditions for survival, warmer SST and a general increase in summer pelagic production resulting from an earlier bloom would also contribute to maximize juvenile polar cod biomass in late summer in region-years of early ice breakup. It is difficult to tease apart the respective roles of early breakup and high SST as they are highly correlated (Bouchard et al. 2017). In the laboratory, age- 0 polar cod achieved better morphometric and lipid conditions at high temperature $\left(5^{\circ}\right.$ vs. $2^{\circ} \mathrm{C}$ ) or high food ration (2-5 vs. 0.5 prey $\mathrm{ml}^{-1}$ ) (Koenker et al. 2018). The present field study confirms that the zooplankton food available to young polar cod increases with an earlier ice breakup and phytoplankton bloom onset (Fig. 3a, b); and that the biomass of juvenile polar cod in August is limited at low densities of zooplankton (Fig. 4b). The dependence of polar cod recruitment on zooplankton density followed the expected asymptotic curve predicted by theory when predators become saturated beyond some threshold prey concentration (Holling 1959; Cushing and Horwood 1994). Therefore, the emerging proximal mechanism behind the enhancement of juvenile polar cod recruitment with early ice breakup is the maximization of prewinter sizes, and possibly lipid storage, by exposing early hatchers to higher SST and saturating feeding conditions.

Bouchard et al. (2017) reported weaker relationships between epipelagic juvenile polar cod biomass and ice breakup date or spring-summer SST for acoustic surveys conducted in October relative to August or September. They attributed the seasonal deterioration of the relationships to the downward migration of the juveniles leaving the epipelagic layer (Geoffroy et al. 2016), and emphasized the importance of conducting surveys during the appropriate temporal window (Bouchard et al. 2017). In the present study, all relationships involving the backscatter of zooplankton were weaker in September than in August (Online resource 2 to 5). By September, the Calanus species making up the bulk of zooplankton biomass have initiated or completed their seasonal vertical migration to depths $>100 \mathrm{~m}$ (Dawson 1978; Hirche 1997; Darnis and Fortier 2014). Moreover, an earlier ice breakup and phytoplankton bloom accelerate the development of Arctic copepods and hasten their migration to depth (e.g., Ringuette et al. 2002). While the backscatter of larger macro-zooplankton was excluded in our acoustic analyses, zooplankton backscatter recorded at $120 \mathrm{kHz}$ might have included that of other organisms similar in size to large copepods (e.g., small amphipods). Notwithstanding this potential bias, our results suggest that August is the optimal time window for acoustic surveys aiming at capturing the dependence of juvenile polar cod recruitment on the availability of their epipelagic copepod prey.

Extrapolating the ongoing trend in earlier ice breakup in the different regions studied, Bouchard et al. (2017) projected some admittedly unrealistic increases in the biomass of polar cod by mid-century. They concluded that several factors amplified by the ongoing warming of the Arctic would likely limit an eventual proliferation of polar cod, including the reduction in habitat for the ice-associated individuals and the invasion of Arctic seas by competing or predatory subarctic fish species. In the present study, both the backscatter of zooplankton (Fig. 3a) and biomass of juvenile polar cod (Fig. 4a) were maximum for ice breakups occurring from late May to early July and tended to stagnate or decline for earlier ice breakups in May (note the log scales in both Figs. 3, 4). This parallel response suggests that a mismatch between copepods and their food when the ice breaks earlier than June (Leu et al. 2011) could cascade to the recruitment of juvenile polar cod and contribute to limit the population development of this key species in response to climate warming.

\section{Contrasting oceanographic provinces: depth, seabirds, and the recruitment of polar cod}

The Southern Beaufort Sea and the NW Baffin Bay oceanographic provinces are characterized by deep regions and the presence of a large recurrent polynyas (respectively the Cape Bathurst polynya and the North Water-Lancaster Sound polynya complex). The North Water-Lancaster Sound polynya complex in particular is considered an oasis for Arctic predators (Stirling 1980; Brown and Nettleship 1981; Heide-Jørgensen et al. 2013). By contrast, shallow depths $(<100 \mathrm{~m})$ and the resulting absence of warm Atlantic Water limit the abundance of large Calanus copepods and adult polar cod 
in the Kitikmeot (Bouchard et al. 2018; Darnis et al. unpublished data). Over the period covered by the present study (2006-2017), ice breakups in the regions of the Kitikmeot were among the latest and ranged between early July and early September. Unsurprisingly, the average onset date of the phytoplankton bloom was significantly later (Tukey HSD test, $p<0.05$ ) in this province (Fig. 5a).

Similar to the onset date of the bloom, mean zooplankton backscatter in August presented a clear pattern across the three provinces, with high and similar average values in the deep Southern Beaufort Sea and the deep NW Baffin Bay (6.1-9.7 $\mathrm{m}^{2} \mathrm{nmi}^{-2}$ across regions), and low values $\left(<2 \mathrm{~m}^{2}\right.$ $\mathrm{nmi}^{-2}$ ) in the shallow Kitikmeot (Fig. 5b). Late ice breakup and phytoplankton bloom, the low abundance of zooplankton prey, and a scarcity of adult polar cod (Bouchard et al. 2018) likely resulted in low juvenile polar cod biomass in the Kitikmeot (Fig. 5c).

In all regions of the Southern Beaufort Sea and the NW Baffin Bay oceanographic provinces, mean zooplankton backscatter exceeded the $5 \mathrm{~m}^{2} \mathrm{nmi}^{-2}$ threshold (Fig. 5b) under which juvenile polar cod recruitment seems limited (Fig. 4b). Interestingly, despite non-limiting prey density in both provinces, generally higher mean and maximum juvenile polar cod biomasses were observed in the Southern Beaufort Sea than in NW Baffin Bay (Fig. 5c). Mostly because of the availability of nesting cliffs (Gaston et al. 2012), piscivorous seabirds including the thick-billed murre (Uria lomvia), northern fulmar (Fulmarus glacialis) and black-legged kittiwake (Rissa tridactyla), are considerably more abundant in the North Water-Lancaster Sound polynya complex of NW Baffin Bay than in the Southern Beaufort Sea (Wong et al. 2014). The availability of zooplankton prey being non-limiting in the two provinces, we suspect that intense avian predation lowered juvenile polar cod biomass in NW Baffin Bay relative to the Southern Beaufort Sea (topdown instead of bottom-up control). While energy transfer from lower trophic levels to fish and marine mammals through polar cod could be similar in the two provinces, we suggest that intense avian predation on juvenile polar cod in the North Water-Lancaster Sound polynya complex increases overall energy transfer to higher trophic levels. Our results quantitatively confirm the reputation of the North Water as a biological hotspot, further justifying the transformation of the Pikialasorsuaq region into an international protected area under Inuit management (see Eegeesiak et al. 2017).

Acknowledgements We thank the officers and crew of the CCGS Amundsen and F/V Frosti for their dedication and professionalism. We are grateful to the several technicians and colleagues who contributed to sampling and analysis over the years. The National Oceanic and Atmospheric Administration graciously lent the transducers used on board the Frosti, and Yvan Simard (Fisheries and Oceans Canada) lent the transceivers. Experts at the Canada Excellence Research Chair on remote sensing of Canada's new Arctic frontier provided the MODIS data and valuable recommendations for their processing. We would also like to thank Franz Mueter, Hauke Flores and two anonymous reviewers for their comprehensive and highly constructive comments. Thanks to the Beaufort Region Environmental Assessment (BREA) program of Indian and Northern Affairs Canada, the Network of Centres of Excellence ArcticNet, the Canadian International Polar Year, and the Canada Foundation for Innovation (Amundsen Science) for financial support. ML received scholarships from the Natural Sciences and Engineering Research Council of Canada (NSERC). This is a contribution to Québec-Océan at Université Laval, ArcticNet, and the Canada Research Chair on the response of Arctic marine ecosystems to climate warming.

Data availability Hydroacoustic data collected onboard the CCGS Amundsen are available at https://www.polardata.ca (CCIN Reference No.: 12841).

\section{Compliance with ethical standards}

Conflict of interest The authors declare that they have no conflict of interest.

Ethical approval All applicable international, national, and/or institutional guidelines for the care and use of animals were followed. Research licenses obtained since 2014 for ArcticNet annual expeditions onboard the CCGS Amundsen are listed at https://www.arcticnet.ulava 1.ca/research/expedition2018.php.

Open Access This article is distributed under the terms of the Creative Commons Attribution 4.0 International License (http://creativeco mmons.org/licenses/by/4.0/), which permits unrestricted use, distribution, and reproduction in any medium, provided you give appropriate credit to the original author(s) and the source, provide a link to the Creative Commons license, and indicate if changes were made.

\section{References}

Ardyna M, Babin M, Gosselin M, Devred E, Rainville L, Tremblay JE (2014) Recent Arctic Ocean sea ice loss triggers novel fall phytoplankton blooms. Geophys Res Lett 41:6207-6212

Arrigo KR, Perovich DK, Pickart RS, Brown ZW, van Dijken GL, Lowry KE, Mills MM et al (2012) Massive phytoplankton blooms under Arctic Sea ice. Science 336:1408-1408

Arrigo KR, van Dijken GL (2004) Annual cycles of sea ice and phytoplankton in Cape Bathurst polynya, southeastern Beaufort Sea, Canadian Arctic. Geophys Res Lett 31:L08304

Arrigo KR, van Dijken GL (2015) Continued increases in Arctic Ocean primary production. Prog Oceanogr 136:60-70

Arrigo KR, van Dijken GL, Pabi S (2008) Impact of a shrinking Arctic ice cover on marine primary production. Geophys Res Lett 35:L19603

Assmy P, Fernadez-Mendez M et al (2017) Leads in Arctic pack ice enable early phytoplankton blooms below snow-covered sea ice. Sci Rep 7:40850

Barber D, Marsden R, Minnett P, Ingram G, Fortier L (2001) Physical processes within the North Water (NOW) Polynya. Atmos-Ocean 39:163-166

Benoit D, Simard Y, Fortier L (2014) Pre-winter distribution and habitat characteristics of polar cod (Boreogadus saida) in southeastern Beaufort Sea. Polar Biol 37:149-163 
Bouchard C, Fortier L (2008) Effects of polynyas on the hatching season, early growth and survival of polar cod Boreogadus saida in the Laptev Sea. Mar Ecol Prog Ser 355:247-256

Bouchard C, Fortier L (2011) Circum-arctic comparison of the hatching season of polar cod Boreogadus saida: a test of the freshwater winter refuge hypothesis. Prog Oceanogr 90:105-116

Bouchard C, Mollard S, Suzuki K, Robert D, Fortier L (2016) Contrasting the early life histories of sympatric Arctic gadids Boreogadus saida and Arctogadus glacialis in the Canadian Beaufort Sea. Polar Biol 39:1005-1022

Bouchard C, Geoffroy M, LeBlanc M, Majewski A, Gauthier S, Walkusz W, Reist JD et al (2017) Climate warming enhances polar cod recruitment, at least transiently. Prog Oceanogr 156:121-129

Bouchard C, Geoffroy M, LeBlanc M, Fortier L (2018) Larval and adult fish assemblages along the Northwest Passage: the shallow Kitikmeot and the ice-covered Parry Channel as potential barriers to dispersal. Arctic Sci 4:781-793

Brown RGB, Nettleship DN (1981) The biological significance of polynyas to Arctic colonial seabirds. In: Stirling I, Cleator H (Eds.) Polynyas in the Canadian Arctic. Occasional Paper 45. Canadian Wildlife Service, Ottawa, pp 59-66

Carmack EC, Kulikov EA (1998) Wind-forced upwelling and internal Kelvin wave generation in Mackenzie Canyon, Beaufort Sea. J Geophys Res Oceans 103:18447-18458

Carmack EC, Macdonald RW, Jasper S (2004) Phytoplankton productivity on the Canadian Shelf of the Beaufort Sea. Mar Ecol Prog Ser 277:37-50

Cushing DH, Horwood JW (1994) The growth and death of fish larvae. J Plankton Res 16:291-300

Daase M, Falk-Petersen S, Varpe O, Darnis G, Søreide JE, Wold A, Leu E et al (2013) Timing of reproductive events in the marine copepod Calanus glacialis: a pan-Arctic perspective. Can J Fish Aquat Sci 70:871-884

Darnis G, Barber DG, Fortier L (2008) Sea ice and the onshore-offshore gradient in pre-winter zooplankton assemblages in southeastern Beaufort Sea. J Mar Syst 74:994-1011

Darnis G, Fortier L (2014) Temperature, food and the seasonal vertical migration of key arctic copepods in the thermally stratified Amundsen Gulf (Beaufort Sea, Arctic Ocean). J Plankton Res 36:1092-1108

Darnis G, Robert D, Pomerleau C, Link H, Archambault P, Nelson RJ, Geoffroy M et al (2012) Current state and trends in Canadian Arctic marine ecosystems: II. Heterotrophic food web, pelagicbenthic coupling, and biodiversity. Clim Change 115:179-205

David C, Lange B, Krumpen T, Schaafsma F, van Franeker JA, Flores $\mathrm{H}$ (2016) Under-ice distribution of polar cod Boreogadus saida in the central Arctic Ocean and their association with sea-ice habitat properties. Polar Biol 39:981-994

Dawson JK (1978) Vertical distribution of Calanus hyperboreus in the central Arctic Ocean. Limnol Oceanogr 23:950-957

Demer D, Berger L, Bernasconi M, Bethke E, Boswell K, Chu D, Domokos R et al. (2015) Calibration of acoustic instruments. ICES Cooperative Research Report 133

Eegeesiak O, Aariak E, Kleist KV (2017) People of the ice bridge: the future of the Pikialasorsuaq. Report of the Pikialasorsuaq Commission, Inuit Circumpolar Council Canada, Ottawa

Fortier L, Ponton D, Gilbert M (1995) The match/mismatch hypothesis and the feeding success of fish larvae in ice-covered southeastern Hudson Bay. Mar Ecol Prog Ser 120:11-27

Fortier L, Reist JD, Ferguson SH, Archambault P, Matley J, Macdonald RW, Robert D, Darnis G, Geoffroy M, Suzuki K, Falardeau M, MacPhee SA, Majewsi AR, Marcoux M, Sawatzky CD, Atchison S, Loseto LL, Grant C, Link H, Asselin NC, Harwood LA, Slavik D, Letcher RJ (2015) Arctic change: impacts on marine ecosystems and contaminants. In: Stern GA, Gaden A (eds) From Science to Policy in the Western and Central Canadian Arctic: An
Integrated Regional Impact Study (IRIS) of Climate Change and Modernization. ArcticNet, Québec, pp 200-253

Fortier M, Fortier L, Michel C, Legendre L (2002) Climatic and biological forcing of the vertical flux of biogenic particles under seasonal Arctic sea ice. Mar Ecol Prog Ser 225:1-16

Francois R, Garrison G (1982) Sound absorption based on ocean measurements. Part II: boric acid contribution and equation for total absorption. J Acoust Soc Am 72:1879-1890

Frank KT (1997) The utility of early life history studies and the challenges of recruitment prediction. In: Chambers RC, Trippel EA (eds) Early life history and recruitment in fish populations. Chapman and Hall, London, pp 495-512

Gaston AJ, Mallory ML, Gilchrist HG (2012) Populations and trends of Canadian Arctic seabirds. Polar Biol 35:1221-1232

Geoffroy M, Majewski A, LeBlanc M, Gauthier S, Walkusz W, Reist JD, Fortier L (2016) Vertical segregation of age-0 and age-1+ polar cod (Boreogadus saida) over the annual cycle in the Canadian Beaufort Sea. Polar Biol 39:1023-1037

Gradinger RR, Bluhm BA (2004) In-situ observations on the distribution and behavior of amphipods and Arctic cod (Boreogadus saida) under the sea ice of the High Arctic Canada Basin. Polar Biol 27:595-603

Haecky P, Jonsson S, Andersson A (1998) Influence of sea ice on the composition of the spring phytoplankton bloom in the northern Baltic Sea. Polar Biol 20:1-8

Heide-Jørgensen MP, Burt LM, Hansen RG, Nielsen NH, Rasmussen M, Fossette S, Stern H (2013) The significance of the North Water Polynya to arctic top predators. Ambio 42:596-610

Hirche HJ (1997) Life cycle of the copepod Calanus hyperboreus in the Greenland Sea. Mar Biol 128:607-618

Holling CS (1959) Some characteristics of simple types of predation and parasitism. Can Entomol 91:385-398

Horner RA (1985) Ecology of sea ice microalgae. In: Horner RA (ed) Sea ice biota. CRC Press, Cincinnati, pp 83-103

Hunt GL Jr, Stabeno P, Walters G, Sinclair E, Brodeur RD, Napp JM, Bond NA (2002) Climate change and control of the southeastern Bering Sea pelagic ecosystem. Deep Sea Res Part II 49:5821-5853

Kahru M, Brotas V, Manzano-Sarabia M, Mitchell B (2011) Are phytoplankton blooms occurring earlier in the Arctic? Glob Change Biol 17:1733-1739

Koenker BL, Copeman LA, Laurel B (2018) Impacts of temperature and food availability on the condition of larval Arctic cod (Boreogadus saida) and walleye pollock (Gadus chalcogrammus). ICES J Mar Sci 25:256. https://doi.org/10.1093/icesjms/fsy052

Laurel BJ, Knoth BA, Ryer CH (2016) Growth, mortality, and recruitment signals in age- 0 gadids settling in coastal Gulf of Alaska. ICES J Mar Sci 73:2227-2237

Leggett WC, Frank KT (2008) Paradigms in fisheries oceanography. Oceanogr Mar Biol Annu Rev 46:331-363

Leu E, Søreide J, Hessen D, Falk-Petersen S, Berge J (2011) Consequences of changing sea-ice cover for primary and secondary producers in the European Arctic shelf seas: timing, quantity, and quality. Prog Oceanogr 90:18-32

Lønne O, Gulliksen B (1989) Size, age and diet of polar cod, Boreogadus saida (Lepechin 1773), in ice covered waters. Polar Biol 9:187-191

Mackenzie KV (1981) Nine-term equation for sound speed in the oceans. J Acoust Soc Am 70:807-812

Madureira LS, Everson I, Murphy EJ (1993) Interpretation of acoustic data at two frequencies to discriminate between Antarctic krill (Euphausia superba Dana) and other scatterers. J Plankton Res 15:787-802

Marchese C, Albouy C, Tremblay JE, Dumont D, D'Ortenzio F, Vissault S, Bélanger S (2017) Changes in phytoplankton bloom 
phenology over the North Water (NOW) polynya: a response to changing environmental conditions. Polar Biol 40:1721-1737

Martin J, Tremblay JE, Gagnon J, Tremblay G, Lapoussière A, Jose C, Poulin M et al (2010) Prevalence, structure and properties of subsurface chlorophyll maxima in Canadian Arctic waters. Mar Ecol Prog Ser 412:69-84

Melnikov I, Chernova N (2013) Characteristics of under-ice swarming of polar cod Boreogadus saida (Gadidae) in the Central Arctic Ocean. J Ichthyol 53:7-15

Michaud J, Fortier L, Rowe P, Ramseier R (1996) Feeding success and survivorship of Arctic cod larvae, Boreogadus saida, in the northeast water Polynya (Greenland Sea). Fish Oceanogr 5:120-135

Myers RA (1998) When do environment-recruitment correlations work? Rev Fish Biol Fish 8:285-305

Nakagawa S, Schielzeth H (2013) A general and simple method for obtaining $\mathrm{R}^{2}$ from generalized linear mixed-effects models. Methods Ecol Evol 4:133-142

National Snow and Ice Data Center (2018) Arctic Sea Ice News and Analysis. https://nsidc.org/arcticseaicenews/. Accessed 20 July 2018

Platt T, White GN III, Zhai L, Sathyendranath S, Roy S (2009) The phenology of phytoplankton blooms: ecosystem indicators from remote sensing. Ecol Model 220:3057-3069

R Core Team (2015) R: A language and environment for statistical computing. R Foundation for Statistical Computing, Vienna

Ringuette M, Fortier L, Fortier M, Runge JA, Belanger S, Larouche P, Weslawski JM et al (2002) Advanced recruitment and accelerated population development in Arctic calanoid copepods of the North Water. Deep Sea Res Part II 49:5081-5099

Sakshaug E, Slagstad D (1991) Light and productivity of phytoplankton in polar marine ecosystems: a physiological view. Polar Res 10:69-86

Scott JB, Marshall GJ (2010) A step-change in the date of sea-ice breakup in western Hudson Bay. Arctic 63:155-164

Søreide JE, Hop H, Carroll ML, Falk-Petersen S, Hegseth EN (2006) Seasonal food web structures and sympagic-pelagic coupling in the European Arctic revealed by stable isotopes and a two-source food web model. Prog Oceanogr 71:59-87
Søreide JE, Leu E, Berge J, Graeve M, Falk-Petersen S (2010) Timing of blooms, algal food quality and Calanus glacialis reproduction and growth in a changing Arctic. Glob Change Biol 16:3154-3163

Stirling I (1980) The biological importance of polynyas in the Canadian Arctic. Arctic 33:303-315

Tremblay JE, Gratton Y, Fauchot J, Price NM (2002) Climatic and oceanic forcing of new, net, and diatom production in the North Water. Deep Sea Res Part II 49:4927-4946

Tremblay JE, Robert D, Varela DE, Lovejoy C, Darnis G, Nelson RJ, Sastri AR (2012) Current state and trends in Canadian Arctic marine ecosystems: I. Primary production Clim Change 115:161-178

Tynan CT, DeMaster DP (1997) Observations and predictions of Arctic climatic change: potential effects on marine mammals. Arctic 50:308-322

Wang Q, Myers PG, Hu XM, Bush ABG (2012) Flow constraints on pathways through the Canadian Arctic Archipelago. Atmos-Ocean 50:373-385

Welch HE, Bergmann MA, Siferd TD, Martin KA, Curtis MF, Crawford RE, Conover RJ et al (1992) Energy flow through the marine ecosystem of the Lancaster Sound Region, Arctic Canada. Arctic 45:343-357

Williams WJ, Carmack EC (2008) Combined effect of wind-forcing and isobath divergence on upwelling at Cape Bathurst, Beaufort Sea. J Mar Res 66:645-663

Wong SN, Gjerdrum C, Morgan KH, Mallory ML (2014) Hotspots in cold seas: the composition, distribution, and abundance of marine birds in the North American Arctic. J Geophys Res Oceans 119:1691-1705

Publisher's Note Springer Nature remains neutral with regard to jurisdictional claims in published maps and institutional affiliations. 